\title{
The Inefficiency of Zakat Manage- ment in BAZNAS Sragen Indonesia
}

DOI 10.18196/AIIJIS.2020.0121.209-227

\section{AGUS WAHYU TRIATMO' ${ }^{1}$ RAVIK KARSIDI' ${ }^{2}$ DRAJAT TRI KARTONO ${ }^{3}$, SUWARTO ${ }^{4}$}

Community Development Department ${ }^{1}$, Postgraduate School Universitas Sebelas Maret², Surakarta, Indonesia, Faculty of Social and Political Sciences ${ }^{3}$, Universitas Sebelas Maret Surakarta, Indonesia, Faculty of Agriculture Universitas Sebelas Maret ${ }^{4}$, Surakarta, Indonesia Correspondence Email: aguswt69@gmail.com ${ }^{1}$

\begin{abstract}
The purpose of this paper is to analyze the problems of zakat governance in Indonesia, with the case study of BAZNAS in Sragen Regency. This study was qualitative research with the perspective of institutional theory. Results indicated that: (1) BAZNAS Sragen has a relatively high transaction cost due to several factors, particularly the costs of seeking information and monitoring; (2) BAZNAS Sragen conducts asymmetric information which is characterized by the lack of transparency, accountability, and fairness; (3) BAZNAS Sragen has a potential to perform opportunistic behavior in the form of political contamination in the distribution of ZIS funds. The less efficient governance causes the less optimal performance of BAZNAS Sragen, either in the limited amount of zakat fundraising or in its performance in empowering the poor.

Keywords: philanthropic institutions, governance, transaction cost, asymmetric information, performance
\end{abstract}

\section{INTRODUCTION}

The tradition of philanthropy among Muslims in Indonesia in the last three decades has developed dynamically. Among those phenomenal developments is the emergence of various zakat institution, either conducted by the government or several private sectors. The Indonesian government establishes the National Zakat Board (Badan Amil Zakat Nasional, BAZNAS) at the level of central, provincial, and regency. The zakat institution presents in every province or regency in Indonesia. According to the Head of BAZNAS, there are at least 520 Regency BAZNAS, 34 Provincial BAZNAS, and 1 Central BAZNAS. Meanwhile, there are 255 Zakat Board Organization (Lembaga Amil 
Zakat, LAZ) from private sectors. ${ }^{1}$

Nevertheless, the large number of zakat institution is not ensued with the people's awareness in fulfilling zakat activities through these zakat institutions. Most people prefer to pay zakat directly to the mustahik or the recipients who are eligible to receive zakat. As an illustration, Dompet Dhuafa Republika in 2009 had conducted a survey on people's assumption about zakat mal in Jabotabek (Jakarta, Bogor, Tangerang, and Bekasi). It was found out that there are only 2,1\% who submitted zakat through zakat institution. Meanwhile, 33,2\% submitted zakat through mustahik, 18,3\% to mosques, $2,1 \%$ to kiai or ulama, $2,1 \%$ to social organizations, the rests did not answer. $^{2}$

The phenomenon of the low public awareness in submitting zakat through zakat management organizations is a challenge for the zakat institution. On the other hand, it also shows that the performance of the zakat management organization has not been optimal. According to Lisa, and Bukowski, the low performance of a zakat management organization is caused by many unresolved problems surrounding the management of the zakat institution. ${ }^{3}$ According to them, the problems of zakat management are at least caused by two factors, internal and external. The internal problems are: (1) the zakat institution leadership is not way professional, (2) the low availability of the infrastructures of the zakat management, such as the office buildings, administration system, and information technology. Meanwhile, the external factor is the low level of public trust to the zakat management organization due to the lack of intensive publication through media.

BAZNAS Sragen can be considered as a unique zakat management organization. It has gained a lot of achievements but, unfortunately, its performance has not been optimal. Institutionally, during three consecutive years (2013, 2014, 2015), BAZNAS Sragen has successfully achieved Zakat Award, a national award given by the government. The first Zakat Award in 2013 was achieved for its success in integrating the poverty alleviation program between BAZNAS and the Local Government of Sragen Regency. The integration was seen in the form of the synergy of mustahik data and the Poverty Management Integrated Service Unit (Unit Pelayanan Terpadu Penanggulangan Kemiskinan, UPTPK) of Sragen Regency. The second Zakat Award was achieved in 2014 for its quick response in serving the public. The third Zakat Award was achieved in 2015 for its well-defined and systematic procedure, stated in the form of a Standard Operational Procedure (SOP), in 
organizing zakat, including the mustahik data collection, data verification, and zakat distribution. ${ }^{4}$

However, the aforementioned achievements and awards do not affect the public trust to pay zakat through BAZNAS Sragen. Civil employees, who are the target of its operation, have not entirely become the muzakki (zakat payers) in this organization. From the total of 13.500 civil employees, only $36 \%$ becomes the muzzaki of BAZNAS. Likewise, there are no companies, private or government business entities which pay their zakat through BAZNAS Sragen. The zakat, infak and shodaqoh (ZIS) funds successfully collected by BAZNAS Sragen are still in the range of 150-200 million IDR per month. ${ }^{5}$ Compared to BAZNAS in Karanganyar Regency, which managed to collect its ZIS funds reaching 1 billion IDR every month, the funds of BAZNAS Sragen are still minimal. ${ }^{6}$ The paradox between the organization's governance and performance in collecting ZIS funds raise questions: (1) Why is the performance of BAZNAS Sragen considered not optimal?, (2) Are there any problems in the governance of BAZNAS Sragen? This article aims at describing the problems in the institutional governance of BAZNAS Sragen.

\section{LITERATURE REVIEW}

\section{A. Previous Research}

The interesting theme of zakat management has invited many scholars to conduct research on this field. Kadir (et.al) conducts a research on the muzzaki of 462 companies in Malaysia. ${ }^{7}$ The research finds that the components of the company, including the board of directors, the stock ownership, the size of the company, and the profitability level do not influence the zakat payment of the business organizations. Merlinda (et.al) in their research finds that the understanding of moderate law, nishab (the limit of wealth ownership), and the period of zakat payment are the factors influencing the decision of a Muslim in submitting zakat. ${ }^{8}$

Meanwhile, Lisa conducts a research about factors that support and obstruct the implementation of zakat management. ${ }^{9}$ Some of the supporting factors are the socialization of zakat in the society and the support of the public figures. On the other hand, the obstructing factors are the lack understanding of the people, the quality of human resources of the administrators, the lack of facilities and infrastructures. Norazlina conducts a research on zakat institutions organized by the government. ${ }^{10}$ The research states that the system of zakat payment, the computerized zakat, the audit committee, and 
the decentralization are the factors influencing zakat management in Malaysia. Thus, Norazlina suggests that modernization in zakat management is needed. ${ }^{11}$ Bukowski states that zakat has not been able to give contribution to the economic development in Pakistan due to the mismanagement and corruption in zakat management. ${ }^{12}$

Kadir and Merlinda focus on factors influencing individual and company muzzaki in submitting zakat. ${ }^{13}$ Meanwhile, Bukowski, Lisa and Norazlina focus their research on the management of zakat organizations. ${ }^{14}$ However, those research stated above have not analyzed zakat management organizations comprehensively. Therefore, the perspective of institutional theory, as used in this research, is needed.

\section{B. Institutional Theory as Perspective}

This research uses institutional theory as the perspective. According to Williamson institution is formal and informal rules as well as its enforcement mechanism forming individual and organizational behaviors in society. ${ }^{15}$ Institution has four reciprocal interconnected stages, they are: social embeddedness or informal institution embedded within society; institutional environment consisting of formal rules; good governance to reduce transaction cost; and agency theory or the management of natural and human resources.

Within the perspective of institutional governance, zakat payment by muzakki to zakat institution is a contractual relationship between the principal and the agent. Muzakki or the principal is a property right holder. The property is in the form of zakat, infaq, shodaqah, or wakaf (usually called as 'ziswaf') which is prepared to be transferred to the agent or the zakat institution. Meanwhile, zakat institution is an organization arranged to distribute the mandated-funds or ziswaf funds to mustahik based on the rules. zakat institution must be responsible for this zakat management and report it to muzzaki or other stakeholders.

The relationship between the principal and the agent would run efficiently if the governance system applied are able to minimize the transaction cost. ${ }^{16}$ Governance system is the rule of the game forming the behaviors of other parties involved in the transaction process. Rule of game aims to create good order that can reduce uncertainty and conflict, as well as create mutual gains. ${ }^{17}$ Rule of game also aims to reduce the transaction cost and to prevent asymmetric information. 
Transaction cost is fund used to negotiate, measure, and force an exchange. ${ }^{18}$ Transaction cost may also include three wide categories, including: (1) the cost of seeking information, (2) the cost of bargaining, the decision to execute contract, (3) the cost of monitoring, forcing, and fulfilling/conducting. ${ }^{19}$ Transaction cost is often used to measure the efficiency of the institutional design. The higher the transaction cost the less efficient the designedinstitution. ${ }^{20}$

Agency theory states that, occasionally, there is a conflict of interest in the contractual relationship between the principal and the agent, where the agent has more access to the company information compared to the principal. This phenomenon is called as "asymmetric information". ${ }^{21}$ The unbalanced ownership of information causes the agent to perform "opportunistic behavior", or acts that benefit themselves but harming other (the principal), including moral hazard and diverse selection. ${ }^{22}$ Consequently, the institutional governance can be more efficient when asymmetric information can be prevented.

In the context of muzzaki and zakat institution relationship, transaction cost can be reduce when muzakki gets: (1) adequate information about the quality, the types, and the prize of the programs, (2) easiness in ZIS payment transaction, (3) easiness to conduct monitoring program to the agent in fulfilling the contract. On the other hand, asymmetric information in the context of zakat management can be prevented when the agent accommodate the principles of good governance in organizing zakat institution. Good governance is actually a concept originated from agency theory. It has four main principles, they are: transparency, accountability, responsibility, and fairness. ${ }^{23}$

\section{METHODOLOGY}

This is a qualitative research. ${ }^{24}$ Qualitative is used for its naturalistic characteristic. Thus, it is possible to identify, describe the background, define systematically, and provide details about institutional governance. This research is also a case study in an Islamic philanthropy organization managed by the local government of Sragen Regency, namely Badan Amil Zakat Nasional (BAZNAS) Sragen Regency, Central Java, Indonesia. ${ }^{25}$ The technique of data collection is in-depth interview with the board of leaders, either the consideration board, daily executive board, muzakki, and mustahik. Besides, the data is also collected through observation. The secondary technique documentation used in collecting the data is available in the organization archives.

The data collected were analyzed inductively; by means of conclusion 
which was broaden, developed, and started in field; from a fragmentary to an interrelated data. The data analysis was done in four stages: data collection, data reduction, data presentation, and drawing conclusion. ${ }^{26}$

\section{RESULT AND ANALYSIS}

\section{A. Profile of BAZNAS Sragen}

Similar to other BAZNAS, the establishment of BAZNAS Sragen was based on the opinions of several ulama stating that the management of zakat is the responsibility and the authority of the government. ${ }^{27}$ According to the Head of the Indonesian Ulema Council (Majelis Ulama Indonesia, MUI) Sragen Regency, based on Surah At-Tawbah 9:103 the management of zakat is the government's domain. ${ }^{28}$

The management of zakat conducted by the local government of Sragen Regency was started in 1991, when the Minister of Religious Affairs and the Minister of Home Affairs released Joint Decree Letter or No.29 of 1991 on the management of National Board of Zakat, Infaq, and Shodaqah (Badan Amil Zakat Infak Shodaqoh, BAZIS). In response to the Joint Decree Letter, the Local Government of Sragen along with the ulama from various Islamic community organizations, including Nahdlotul Ulama (NU), Muhammadiyah, Indonesian Islamic Dakwah Institution (Lembaga Dakwah Islam Indonesia, LDII), and Majlis Tafsir Al-Quran (MTA); decided to found BAZIS. The establishment of this organization was based on the Decision Letter of Sragen Distric Head No. 451.5/06/212/1991. Following the issue of Act No.38 of 1999 and Act No. 23 of 2011 on zakat management, BAZIS adjusted its organization and changed its name into Board of Zakat (Badan Amil Zakat, BAZ) and National Zakat Board (BAZNAS) Sragen Regency.

According to Act No. 23 of 2011, BAZNAS is a non-structural government organization (article 5, verse 3) having two functions: (1) as a government representation in managing zakat with the main duty as a facilitator, coordinator, and supervisor of all zakat institution in Sragen Regency, (2) as an operator of zakat management in the district. Regency BAZNAS obliges to report the realization of their main duties and functions to Province BAZNAS and the regency government (verse 29). In the context of BAZNAS Sragen, the report of the zakat management implementation is done in plenary session, attended by all the members of considering board, principals, and employees of BAZNAS.

Even though there are no obligatory rules, the principals of BAZNAS is 
designed to be integrated with the Regency Government. Structurally, BAZNAS principals are under the Board of Consideration, consisting of the Regent and the Vice Regent, the Chairman of MUI Sragen, and the Head of Ministry of Religious Affairs of Sragen Regency. The slightly feudalistic leadership is a form of a local wisdom, which is obtained to get legitimacy before the people of Sragen Regency, particularly among the civil employees as the prospective muzzaki.

As the operator of zakat management, BAZNAS Sragen is asked to collect, distribute, and empower the ZIS funds. In order to conduct these responsibilities, all zakat institution in Sragen Regency are agreed to divide their working areas. This effort aims to avoid overlapping and seizure working areas among the zakat organizations. Thus, conducive working environment can be gained. In the division of the working areas, BAZNAS acquires special operating areas among the civil employees, Indonesian Army (Tentara Nasional Indonesia, TNI), Indonesian National Police (Kepolisian Republik Indonesia, POLRI), StateOwned Enterprises (Badan Usaha Milik Negara, BUMN), Local GovernmentOwned Enterprises (Badan Usaha Milik Daerah, BUMD), and other private companies. $^{29}$

Based on the division of the working areas as stated above, it is found out that muzakki BAZNAS is a community of fixed income people, including the civil employees, TNI and Polri, as well as the chairman of BUMD and private companies. BAZNAS uses fundraising strategy or sallary deduction. In this strategy, the chairman of BAZNAS approaches the chairman of all government or local institutions and persuades them so that the chairman and the staffs are willing to pay zakat through BAZNAS. However, even until this research was completed not all civil employees were willing to pay zakat through BAZNAS.

In the era of digital information, BAZNAS organizers also utilize information technology (IT). Among those applications is Management Information System (SIM), in which virtual office (kantor maya, Kantaya) exists. Using this application, BAZNAS is connected through internet to all the government bureaucracy in Sragen Regency. In the distribution of zakat, BAZNAS utilizes Harmonious Management Information System of Sukowati Residents (Sistim Informasi Manajemen Serasi Warga Sukowati, SIMSARASWATI). SIMSARASWATI is a data service center for the poors in Sragen Regency organized by Integrated Service Unit of Poverty Alleviation (Unit Pelayanan Terpadu Penanggulangan Kemiskinan, UPT PK). All mustahik are registered on this 
system. The whole services are finally inserted in the Center of Data and Information (Pusat Data dan Informasi, PUSDI), which is functioned as filtration, so that mustahik would not receive the same aids for several years. ${ }^{30}$

Even though the amount of its zakat collection have not been large, the management of BAZNAS Sragen can be categorized as the best compared to other identical organizations in other regions. Among those predominance is that BAZNAS Sragen has a SOP in zakat management, started from the collection, the submission, to the empowerment. Besides, there is a technology information based zakat management. As an appreciation given by the government, BAZNAS Sragen received zakat awards in three consecutive years: 2013, 2014, 2015.

\section{B. BAZNAS Sragen from Institutional Perspective}

\section{Islamic Norm as the Rules}

Islam in the source of norm and law of zakat management. In order to guarantee that the zakat management is based on Islamic teaching, BAZNAS is guided by the fatwa and guidance of MUI. The Islamic concept of zakat is very clear. However, there are a lot of development during the implementation. Thus, modernization of thought or ijtihad is needed. ${ }^{31}$

In conducting ijtihad, MUI does not only hold on one madzhab, but it also compares four Imam madzhab. After comparing, MUI searches for the most appropriate one to be implemented in Sragen. In the case of muzakki for instance, MUI follows the Imam Malik (711-795 M) statement, who states that people who are eligible to conduct zakat are all professions which earn money. It is different from conventional mahdzab stating that muzakki are only those come from agricultural, farming, mining, trading professions.

In response to profession zakat, MUI states that the haul (the limit of the wealth owned by muzakki) is one year. According to MUI, almost all people who have fixed income are actually considered as fulfilling the criteria of one year haul for the estimation of salary is actually defined for the period of a year, thus, only the payment is given on each month. Therefore, profession zakat has been fulfilled the criteria of haul.

The next issue is the use of zakat for public facilities. In contrast to conventional thinking, which is oriented towards Imam Shafi'i (767-819 M), the recipient of zakat is an independent servant (abdun harun), not for public facilities. In this case, the MUI follows the opinion stated in the Tafsir book written by Munir Khalil al Bantani, Tafsir Fauzi, that the name fi sabilillah is fi 
sbilil khair (for the path of goodness). Therefore, the use of zakat for public facilities, including building bridges, highways, and mosques; is permissible. ${ }^{32}$

Among those opinions stated by MUI as the Board of Consideration, it can be concluded that BAZNAS management is actually based on modern and inclusive Islamic thoughts. Consequently, there is actually no reason for BAZNAS for not becoming a professional organization equipped with good governance.

\section{The Transaction Cost in BAZNAS Governance}

Based on the point of view of institutional, the efficiency of the organizational governance of BAZNAS Sragen is determined by the ability of minimizing the transaction cost. ${ }^{33}$ Transaction cost can be divided into three components: information cost, negotiation cost, and monitoring cost. These three components are used to analyze the management of BAZNAS Sragen.

- Information Cost

BAZNAS Sragen does not provide adequate information about the quality, the types, ang the program cost; either from printed, electronic, or social media; to the muzakki or potential muzakki. Zakkaaha as the media connecting BAZNAS and muzakki or the public, only provides photo gallery portraying the organization's activities without any narration, and the financial report about the amount of zakat received by each UPTD. ${ }^{34}$ BAZNAS would give information about the report of its program implementation every year in the plenary meeting. This report is given to the Board of Consideration, not to the muzakki. ${ }^{35}$

Fundraising strategy conducted by BAZNAS to gain prospective muzakki's trust is by establishing Zakat Collector Unit (Unit Pengumpul Zakat, UPZ) which are available in various governmental offices in the Local Government of Sragen. This fundraising strategy does not aim to "sell" the programs but to expect for the muzakki to participate on the programs. Therefore, BAZNAS Sragen does not provide detail information about the quality, the types, and the cost of the programs to the public. Consequently, the public or the muzakki find difficulties in gaining information about the management of zakat. On the other words, the public needs high cost to gain information about the quality, the types, and the cost of the programs. This high cost is possibly the reason why people are reluctant to submit zakat through BAZNAS Sragen.

- Negotiation Cost

In the context of zakat management, negotiation cost is the cost that 
must be submitted by the muzakki to conduct zakat payment transaction with zakat organization as the agent. BAZNAS relies on salary deduction as the transaction technique of zakat payment. Based on the map of muzakki division, almost all benefactors of BAZNAS are civil employees achieving fixed income for their institution. Thus, the technique of salary deduction is the most efficient technique with low cost of negotiation.

On the other hand, the system of salary deduction cannot be applied to people having no fixed incomes. In order to attract people with no fixed income, BAZNAS prepares zakat technique payment through bank account though it is seldom used. Seen from the negotiation cost, salary deduction technique facilitates potential muzakki to submit their zakat through BAZNAS. Therefore, negotiation cost component is suspected as the obstacle for the potential muzakki, particularly the civil employees to pay zakat through BAZNAS.

- Monitoring Cost

The qualified monitoring system becomes a warranty that an institution is managed well. According to Act No.23 of 2011, the monitoring system of zakat institution can be conducted by the government or the society. BAZNAS uses internal and external monitoring systems. The internal monitoring system is conducted by the Board of Internal Supervisor included in the structure of the management of BAZNAS Sragen. This Board of Supervisor monitors the financial management regularly, once in three months. The results of this monitoring activity becomes the material for internal evaluation.

On the other hand, for the external monitoring system, BAZNAS Sragen prefers to rely on the monitoring system owned and used by the government institution, the Regional Inspectorate Department. The monitoring activity managed by the Inspectorate Department is an obligatory. BAZNAS has not invited professional auditor for its external monitoring activity.

Seen from the efficiency of the monitoring cost, both supervisors of BAZNAS are actually considered as internal supervisors as both of them come from the same institution. They are actually under the Local Government of Sragen Regency. Therefore, the results of the monitoring from both supervisors contain less legitimate value. It would be different if BAZNAS uses professional auditors. On the other words, the cost of the monitoring system is high or people need higher cost to find out the result of the valid and credible results. This factor is probably the cause that makes the people reluctant to pay zakat through BAZNAS. 


\section{Asymmetric Information in BAZNAS Governance}

Asymmetric Information is the information mastery which is unbalance between the agent and the principal. In a contractual relationship between the agent and the principal, there is a tendency where the agent owns more information rather than the principal. If the asymmetric information occurs, the agent has the potential to carry out opportunistic behavior that benefits him unilaterally and is detrimental to the principal. ${ }^{36}$ In the context of zakat management, the principal is the muzakki while the agent is the zakat institution.

According to Afif, a good zakat organization is an organization which can prevent asymmetric information. ${ }^{37}$ Asymmetric information can be prevented when the organization apply good governance in managing its duties. Good governance has four indicators: transparency, accountability, fairness, and responsibility. ${ }^{38}$ In this research, these indicators, except the responsibility, are used to observe the management of BAZNAS Sragen.

- Transparency

The organizers of BAZNAS Sragen has actually realized the importance of transparency in managing zakat organization. As an indication, as stated above, BAZNAS has accommodated the implementation of various internet applications in managing ziswaffunds. With the establishment of internet technology, mistakes and all types of inefficiency in the management of BAZNAS can be avoided. This aspect, probably, gives contribution to the trust shared by the stakeholders towards BAZNAS Sragen.

BAZNAS Sragen also develops transparency by making use of various media. Some of the media are "Zakkaaha" magazine and bulletin, social media- in the form of facebook application or websites. The utilization of these significant media is due to the popularity of social media for the people of Sragen. However, the awareness of the media utilization is not in accordance with the capability of managing the media. Almost all of those media are not managed professionally. Consequently, the contents or the period of the publication have not been ideal. "Zakkaaha" has various contents, including the editor's preface, main paper, "teladan", "tazkiyah", "motivasi", "pojok zakat", "jendela keluarga", "laporan keuangan", "muslimah", and "senyum". However, almost all of the contents are not the original works of the editors or the magazine's team. The contents are the result of "copy-then-paste" activity from other media. ${ }^{39}$ Consequently, the media does not have the ability to attract readers. One of the indications is the aloofness of the muzakki towards 
those media stated above. ${ }^{40}$

The information of the zakat management is only available in the laporan keuangan (financial report) menu, particularly about the amount of zakat received by BAZNAS for the last three months. The activities of BAZNAS are only reported in the form of photos without any adequate description.

As stated before, BAZNAS also uses its website on http://baznassragen.com as well as its Facebook account. However, similar to its printed media Zakkahaa, up until this research has been done, the use of its social media and website is not optimal. Furthermore, the management of the social media and the website is not professional. The website and the Facebook account of BAZNAS Sragen rarely share update information.

The use of the media as the transparency tool is not optimal due to the less capability of the human resources who become the organizers of the media, either from the quality or the quantity. From the quality aspect, the organizers of BAZNAS' media are not the professionals. They are actually the staffs of BAZNAS who are asked to manage the social media. In terms of quantity, the number of the organizers are not adequate. There are only one or two staffs who are assigned to manage all BAZNAS' media.

Consequently, the public, particularly the muzzaki, find difficulties in gaining information about the zakat management. It means that BAZNAS Sragen has not exerted its maximum efforts in accommodating transparency, as part of good governance. Seen from transparency aspect, BAZNAS Sragen has performed asymmetric information which leads to the potential of performing opportunistic behavior.

- Accountability

As the feedback of the mandate given by the muzzaki, BAZNAS as the zakat organizer must be responsible to the muzzaki related to the management of the zakat fund. The public's trust is expected to increase if the organizers perform good accountability. This the importance of accountability for zakat organizers.

BAZNAS implements the accountability through plenary meeting held once a year. The plenary meeting is attended by the Board of Considerations, the Board of Supervisors, the Board of Managers, as well as the daily administrators and staffs. In this plenary meeting, the Board of Managers reports the management of zakat, infak, shadaqah, and wakaf (ziswaf) funds during one year. Besides, programs for the following year are also arranged in this plenary meeting. ${ }^{41}$ 
In accordance with the logic of accountability as stated above, the managers of BAZNAS should also be responsible to the muzakki. However, BAZNAS Sragen does not hold responsible to the muzakki as the principle. BAZNAS Sragen shares its responsibility to the government through the Board of Considerations consisting of the Regent, the Vice Regent, the Chairman of MUI Sragen, and the Head of Ministry of Religious Affairs Sragen. On the other hand, as the plenary meeting is used as the media of sharing its responsibility, actually BAZNAS has not conducted accountability to the muzakki. Therefore, muzakki as the principle do not have any information whether their mandates are delivered to the muzakki or not. This phenomenon shows the asymmetric information done by the agent which potentially leads to opportunistic behavior.

The procedure of responsibility above shows that, institutionally, BAZNAS has two organizational structures: under the principal or the muzakki, and under the government represented by the Board of Considerations. This structures create an ambiguous attitude performed by the organizers. On one side, BAZNAS needs the public's trust or the prospective muzakki. The trust would emerge as the result of the responsibilities conducted by BAZNAS. On the other hand, BAZNAS needs the leadership legitimacy of the Regent and the Vice Regent in order to conduct its duty in collecting zakat from the civil employees under the Local Government of Sragen.

- Fairness

Fairness can be seen in the democratic leadership system. Democratic leadership system enables people to divide the authorities into three fields: legislative, executive, and judiciary. This division of authorities prevent the injustice behaviors. BAZNAS Sragen has performed democratization on its leadership system. Among those democracy activities are: the presence of the Board of Considerations as the legislative representation, the Board of Supervisors as the judiciary representation, and the Board of Managers as the executive representation. However, the Regent and the Vice Regent are included in the Board of Considerations. Thus, there is a domination of authority on one field towards the others. The Board of Managers that gets legitimacy from the Board of Consideration becomes powerfull before the muzakki. Most of the muzakki are the civil employees who are considered as powerless. This kind of structure may potentially create injustice condition in the management of BAZNAS Sragen. At this point, BAZNAS could potentially violate the fairness that leads to asymmetric information then to opportunis- 
tic behavior.

Some of the forms of opportunistic behaviors are moral deviation. Moral deviation is not always in the form of financial benefit for the agent but also in the form of unethical other behaviors. In the context of BAZNAS Sragen, the moral deviation is probably seen in the political contamination of zakat management, particularly in the distribution of zakat which is usually conducted by the Regent. The Regent, in this activity, is the representation of the head of the government as well as the representation of a particular political group. Zakat as a religious institution should be free from this kind of practical politics. ${ }^{42}$

\section{The Performance of BAZNAS Sragen}

The lower the transaction cost, the more efficient the institutional design. The more efficient the institutional design, the higher the performance of the institution. One of the performance done by BAZNAS is zakat collection. The result of zakat collection is 150-200 million rupiah per month. This amount is still considered low compared to the zakat potential of the operation area. As stated above, from the total number of the civil employees in Sragen Regency, only $34 \%$ pays their duty of zakat through BAZNAS. If it is compared with the results of the zakat submission done by BAZNAS of Karanganyar Regency, it is still considered low. BAZNAS Karanganyar could receive 1 billion rupiah every month although, seen from its social-geographical aspect, it has a similar socio-economic background with BAZNAS Sragen.

The other performance indicator is the empowerment of the zakat for empowering the poor. In 2016-2017, most of the zakat funds were distributed in the form of charity. The empowerments were only done in the field of economic, particularly on Small and Middle Scale Business (Usaha Mikro Kecil Menengah, UMKM). In this field, BAZNAS has two programs of empowerment: Capital Financial for the Poor (Modal Usaha Dhuafa, MUD) and Productive Economic Program (Program Ekonomi Produktif, PEP). MUD was implemented by providing capital assistance in the amount of 2 million rupiah to the poor who have initiated business. While PEP was done by providing capital assistance in the amount of 3 million rupiah to the volunteers (mujahid), who also hadinitiated productive economic business, in various religious institutions.

According to the process, the empowerment should fulfill three stages, including enabling, capacity building, and empowering..$^{43}$ However, in fact, 
BAZNAS Sragen only conducts empowering stage. Due to its constraint, BAZNAS do not conduct enabling and capacity building stages. Based on the interview with Dewi, the constraint emerged as the result of the limited number of its human resources. Based on those data stated above, it can be concluded that the performance of BAZNAS Sragen is not optimal. ${ }^{44}$

Based on the results and discussions, it can be concluded that this research justifies the theory stated by Yustika, who says that the transaction cost shows the efficiency of the institutional design. ${ }^{45}$ The result indicated that the insignificant performance of BAZNAS Sragen occurs because its governance has not been efficient. This inefficiency of the governance is due to the high transaction cost and the opportunistic behavior.

\section{CONCLUSION AND RECOMMENDATION}

BAZNAS Sragen relies its organizational design to the Islamic doctrines. According to BAZNAS, the Islamic doctrines about zakat has been remarkably perfect. However, the perfectness of the doctrine does not close the chance for the renewal of Islamic thoughts, by means of actualizing the Islamic doctrines, based on the renewable sociocultural facts.

Unfortunately, within its intuitional design, BAZNAS Sragen is trapped on its governance which tends to be exclusive and static. This tendencyaffects the less efficient institutional design, reflected on the high cost of transactions and the asymmetric information. A further consequence is the performance of BAZNAS; either in collecting, distributing, or empowering the zakat funds

The zakat funds that have been collected by BAZNAS Sragen are still considered low compared to other institutions with almost the same social, economic, and geographical background. The same case also happens in the use of the zakat funds which is only applied for empowering the economic field, particularly on Small and Middle Scale Business. The steps taken during the empowering activities are not complete. BAZNAS only conducts empowerment but shares no activities on enabling and capacity building.

This paper recommends that, BAZNAS Sragen Regency should make improvements to its institutional design by implementing the principles of good governance. Thus it will have an impact on more efficient management and more optimal performance. 


\section{ENDNOTES}

1 Sudibyo, "Strategi Zakat Nasional (PPT Presentasi pada Seminar Nasional "Filantropi Islam Kontemporer) di IAIN Surakarta pada 31 Agustus 2016."

2 Huda, Zakat Perspektif Mikro-Makro: Pendekatan Riset.

3 Lisa, "Implementation of Management Zakat as a Local Revenue." Also see Bukowski, "Social Role of Alms (zakat) in Islamic Economies."

4 Ulin, Wawancara dengan Ulin Tenteng BAZNAS Sragen pada 20 Mei 2017.

5 BAZNAS Karanganyar, "Profil BAZNAS Karanganyar." 2016

6 BAZNAS Karanganyar. 2016

7 Kadir, "Factors Influencing A Business Towards Zakat Payment In Malaysia."

8 Merlinda, Burhan, and Ekawaty, "The Determinant of Moslem's Decision in Performing Commerce Zakat Payment: Case Study in Malang City, East Java Province."

9 Lisa, "Implementation of Management Zakat as a Local Revenue."

10 Wahab and Rahman, "Determinants of Efficiency of Zakat Institutions in Malaysia: A Non-Parametric Approach."

11 Wahab and Rahman.

12 Bukowski, "Social Role of Alms (zakat) in Islamic Economies." See also Lisa, "Implementation of Management Zakat as a Local Revenue." And Merlinda, Burhan, and Ekawaty, "The Determinant of Moslem's Decision in Performing Commerce Zakat Payment: Case Study in Malang City, East Java Province."

13 Kadir, "Factors Influencing A Business Towards Zakat Payment In Malaysia."See also Merlinda, Burhan, and Ekawaty, "The Determinant of Moslem's Decision in Performing Commerce Zakat Payment: Case Study in Malang City, East Java Province."

14 Bukowski, "Social Role of Alms (zakat) in Islamic Economies."

15 Williamson, "The New Institutional Economics/: Taking Stock, Looking Ahead."

16 Yustika, Ekonomi Kelembagaan Definisi, Teori Dan Strategi.

17 Williamson, "The New Institutional Economics/:Taking Stock, Looking Ahead."

18 Yustika, Ekonomi Kelembagaan Definisi, Teori Dan Strategi.

19 Mburu, Collaborative Management of Wildlife in Kenya: An Empirical Analysis of Stakeholders; Participation, Costs and Incentives.

20 Yustika, Ekonomi Kelembagaan Definisi, Teori Dan Strategi.

21 Sufi, "Information Asymmetry and Financing Arrangements: Evidence from Syndicated Loans."

22 Yustika, Ekonomi Kelembagaan Definisi, Teori Dan Strategi.

23 Veronica and Bachtiar, "Corporate Governance, Information Asymmetry, and Earnings Management."

24 Mohajan, "Qualitative Research Methodology in Social Sciences and Related Subjects."

25 Gerring, Case Study Research Principles and Practices.

26 Miles and Huberman, Qualitative Data Analysis: A Sourcebook of New Methods.

27 Fauzia, Filantropi Islam: Sejarah dan Kontestasi Masyarakat Sipil dan Negara di Indonesia. 

Fasilitas Umum pada 26 Mei 2017.

29 Mahmudi, Wawancara dengan Mahmudi Tentang Implementasi Prinsip Akuntabilitas dalam Rapat Pleno pada 27 April 2017.

30 Dewi, "Wawancara Dengan Dewi Pada 27 April 2017."

31 Fazlurrahman, Islam, Sejarah Perkembangan Pemikiran.

32 Minan, Wawancara dengan K.H. MInan Tentang Penggunaan Zakat Untuk Fasilitas Umum pada 26 Mei 2017.

33 Yustika, Ekonomi Kelembagaan Definisi, Teori Dan Strategi.

34 “Zakkaaha," July 2014.

35 "Zakkaaha," October 2017.

36 Amaliah, "Suatu Tinjauan Asimetri Informasi dan Implikasinya Terhadap Manajemen Laba."

37 Afif, "Asimetri Informasi dan Dampaknya Dalam Kebijakan Perusahaan."

38 Baridwan, "'Good Corporate Governance: Aturan-aturan dalam Governing Mechanism'. Seminar Sehari: Issues Application \& Research In Corporate Governance Dalam Rangka Launching Pusat Studi Corporate Governance FE UTY."

39 "Zakkaaha," April 2014.

40 Arif, Wawancara dengan Wawan dan Arif Tentang Majalah Zakkaaha Tidak Menarik Pembaca.

41 Mahmudi, Wawancara dengan Mahmudi Tentang Implementasi Prinsip Akuntabilitas dalam Rapat Pleno pada 27 April 2017.

42 Latief, Politik Filantropi Islam Di Indonesia Negara Pasar Dan Masyarakat Sipil.

43 Wrihatnolo, R.R. dan Dwidjowijoto, Menejemen Pemberdayaan Sebuah Pengantar dan Panduan Untuk Pemberdayaan Masyarakat.

44 Dewi, Wawancara dengan Dewi Tentang Digitalisasi Pengelolaan BAZNAS pada 20 April 2017.

45 Yustika, Ekonomi Kelembagaan Definisi, Teori Dan Strategi.

\section{REFERENCES}

Afif, M. (2015, June). "Asimetri Informasi dan Dampaknya Dalam Kebijakan Perusahaan,” RASAIL J. Pemikir. Islam, 2(1), pp. 23-32.

Amaliah, T. H. (2017, June) "Suatu Tinjauan Asimetri Informasi Dan Implikasinya Terhadap Manajemen Laba,” , pp. 10.

Amir Sufi. (2007, Apr.). "Information Asymmetry and Financing Arrangements: Evidence from Syndicated Loans," Journal Finance, 62, pp. 629-668

Bambang Sudibyo. (2016, August). "Strategi Zakat Nasional” Papper was Presented in a National Seminar Filantropi Islam Kontemporer, IAIN Surakarta, 31-Aug2016.

Baridwan,A. (2003). "Good Corporate Governance: Aturan-aturan dalam Governing Mechanism,” pesented in One Day Seminar: Issues Application EF Research In Corporate Governance Dalam Rangka Launching Pusat Studi Corporate Governance. Yogyakarta: FE UTY. 
BAZNAS Karanganyar. (2016). "Profil BAZNAS Karanganyar."

BAZNAS Sragen, Majalah Zakkaaha, vol. 1, no. 1, Apr-2014.

BAZNAS Sragen, Majalah Zakkaaha, vol. 1, no. 2, July-2014.

BAZNAS Sragen, Majalah Zakkaaha, vol. 1, no. 3, Oct-2017.

Bukowski A. (2014). "Social Role of Alms (zakat) in Islamic Economies," Ann. Etyka W -yciu Gospod. Ann. Ethics Econ. Life Lodz Univ. Press, 17(4), pp. 123-132

Fauzia, A. (2016). Filantropi Islam: Sejarah Dan Kontestasi Masyarakat Sipil Dan Negara Di Indonesia. Yogyakarta: Gading Publising.

Fazlurrahman. (2016). Islam, Sejarah Perkembangan Pemikiran. Bandung: Mizan.

Gerring, J. (2007) Case Study Research Principles and Practices. New York: Cambridge University Press.

Interview with Dewi, Apr 20, 2017.

Interview with KH. Minan, May 25, 2017.

Interview with Mahmudi, May 23, 2017.

Interview with Ulin, May 20, 2017.

Interview with Wawan \& Aris, Sept 5, 2017.

Kadir,M.R. Zulkifli, Z. A. Juliana A.R. dan Surbaini,K.N. (2014, Apr.). "Factors Influencing A Business Towards Zakat Payment In Malaysia,” Int. J. Sci. Commer. Humanit., 2(3)

Latief, H. (2013). Politik filantropi Islam di Indonesia: negara, pasar, dan masyarakat sipil. Yogyakarta: Ombak

Lisa,O. (2015). "Implementation of Management Zakat as a Local Revenue," Journal Asian Sci. Res., 5(8), pp. 418-430, 2015.

Mburu, J. (2002). Collaborative Management Of Wildlife In Kenya: An Empirical Analysis Of Stakeholders; Participation, Costs And Incentives, Socioeconomic Studies on Rural Development. 130. Wissenschaftsverlag vauk Kiel KG.

Meleong, J.L. (1994). Metologi Penelitian Kualitatif. Bandung: PT Remaja Rosdakarya.

Merlinda, S. U. Burhan, dan M. Ekawaty (2016,Apr.). "The Determinant of Moslem's Decision in Performing Commerce Zakat Payment: Case Study in Malang City, East Java Province," Int. J. Soc. Local Econ. Gov., 2(1), pp. 59-68.

Miles, M. B. dan A. M. Huberman, (1984) Qualitative Data Analysis: A Sourcebook Of New Methods. Sage Publications.

Mohajan, H. A. (2018). Qualitative Research Methodology in Social Sciences and Related Subjects," J. Econ. Dev. Environ. People, vol. 7, no. 01, pp. 23-48.

Mutahhari, A. M. (2019, Mart). "The Principle of Ijtihad in Islam," Al-Islam., 10(1), pp. 2-4

N. Huda.(2015). Zakat Perspektif Mikro-Makro: Pendekatan Riset, First edition. Rawamangun. Jakarta: Prenadamedia Group, 2015.

Rodoni, A. dan B. Yaman. (2018, May). "Asymmetric Information and Non-Performing Financing: Study in The Indonesian Islamic Banking Industry,” AlIqtishad J. Ilmu Ekon. Syariah, 10(2).

Soetopo. (1998). Pengantar Penelitian Kualitatif, Dasar-Dasar Teoritis dan Praktis. Surakarta: Pusat Penelitian UNS.

Ujiyantho, M. A. dan Bambang A.P. (2007). "Mekanisme Corporate Governance, 
Manajemen Laba Dan Kinerja Keuangan,” Simp. Nas. Akuntasi X, pp. 26.

Veronica, S. dan Y.S. Bachtiar. (2005). Corporate Governance, Information Asymmetry, And Earnings Management. Journal Akunttasi Dan Keuangan Indonesia. 2(1), pp. 77-106-106.

Wahab, N. A. dan Rahman, A. R. A. (2013, Des.). Determinants of Efficiency of Zakat Institutions in Malaysia: A Non-parametric Approach, AJBA, 6(2), pp. 33-64.

Williamson, O. E.(2000). The New Institutional Economics: Taking Stock, Looking Ahead. J. Econ. Lit., 38(3), pp. 595-613.

Wrihatnolo, R. R dan Dwidjowijoto, R. N. (2007). Menejemen Pemberdayaan Sebuah Pengantar dan Panduan Untuk Pemberdayaan Masyarakat. Jakarta: PT. Elex Media Komputama.

Yustika, A. E.(2008) “Ekonomi Kelembagaan: Definisi, Teori, Dan Strategi,” Malang Bayumedia Publ.

"Zakkaaha." Majalah Zakkaaha, April 2014.

"Zakkaaha." Majalah Zakkaaha, July 2014.

"Zakkaaha." Majalah Zakkaaha, October 2017. 